\title{
O monstro embargado: metamorfose kafkiana em um conto de José Saramago
}

Marcelo Pacheco Soares

IFRJ

\begin{abstract}
Resumo
$\mathrm{Na}$ literatura e nas demais artes, a figura do monstro refere-se, muito comumente, a uma representação do outro, da manifestação de uma alteridade em certa comunidade. Nesse sentido, a novela de Franz Kafka A metamorfose, trazida a público em 1915, fornece, no processo da transformação monstruosa sofrida por seu protagonista, Gregor Samsa, potencial denúncia de uma alienação da identidade a que está submetido o ser humano nas sociedades hodiernas. E, dada a pertinência desse tema na conjuntura do século XX, a poética kafkiana exercerá forte influência sobre a literatura novecentista do Ocidente. O presente artigo investiga algumas dessas manifestações da metamorfose kafkiana na literatura portuguesa, notadamente no conto "Embargo", que José Saramago publica nos anos de 1970, narrativa que, por sua vez, ao estabelecer com a novela de Kafka evidente diálogo intertextual, expõe não somente a alienação, mas também a reificação do homem urbano contemporâneo pela sociedade de consumo.

Palavras-chave: Monstro; Alteridade; Franz Kafka; Contística portuguesa novecentista; José Saramago.
\end{abstract}

\section{Resumen}

En la literatura y en las demás artes, la figura del monstruo se refiere, comúnmente, a una representación del Otro, a la manifestación de una alteridad en determinada comunidad. En este sentido, la novela La metamorfosis, de Franz Kafka, editada en 1915, dispone, en su proceso de transformación monstruosa experimentada por su protagonista, Gregor Samsa, una potencial denuncia de la alienación de la identidad a la que está sometido el ser humano en las sociedades actuales. Y, dada la importancia de este tema en el contexto del siglo XX, la poética kafkiana ejerce gran influencia en la literatura occidental de tal siglo. Este artículo explora algunas de estas manifestaciones de la metamorfosis kafkiana en la literatura portuguesa, sobre todo en el cuento "Embargo", que José Saramago publicó en la década de 1970, una narrativa que, a su vez, estableciendo un franco diálogo intertextual con la novela de Kafka, expone no sólo la alienación sino también la cosificación del hombre urbano contemporáneo por la sociedad de consumo.

Palabras clave: Monstruo; Alteridad; Franz Kafka; Cuentística portuguesa del siglo XX; José Saramago. 
1. KAFKA, Franz. A metamorfose, 2006, p. 13.

\author{
2. KAFKA, Franz. Die
}

Verwandlung, 1916, p. 7.

3. Espaço profícuo para essa constatação é a exposição fotográfica do artista visual João Castilho, em que se apresentam vinte e sete versões em português desse período inaugural da narrativa em imagens de suas edições em livros, a qual se encontra disponível online em http:/ / www.joaocastilho.net/v2/pt/ trabalhos/metamorfose.

4. "Monstros como metáfora do mal". JEHA, Julio. Monstros e monstruosidades na literatura, 2007, p. $20-1$.
"Quando certa manhã Gregor Samsa acordou de sonhos intranquilos, encontrou-se em sua cama metamorfoseado num inseto monstruoso" ". Como é certamente escusado dizer, essa frase inaugura a famosa novela $A$ metamorfose (Die Verwandlung), que o escritor tcheco Franz Kafka publica pela primeira vez em 1915 na revista Die Weißen Blätter, na Alemanha, antes de no ano seguinte trazê-la a lume em edição em livro. Foi quando então essa centenária narrativa entregou uma nova figura ao bestiário da literatura fantástica ocidental: o monstro Samsa.

É claro que, embora se apresente como um caminho fácil, não identificamos a monstruosidade do Samsa transformado em inseto necessariamente baseados no uso do adjetivo monstruoso que encontramos na tradução para o texto, da qual aqui fazemos uso, empreendida por Modesto Carone. No original (“Als Gregor Samsa eines Morgens aus unruhigen Träumen erwachte, fand er sich in seinem Bett zu einem ungeheueren Ungeziefer verwandelt"2), a palavra ungeheueren abriga, mais precisamente, uma acepção de grandeza excessiva (e essa ideia de excesso lemos como não natural), desse modo, a princípio, apenas tangenciando o significado do termo utilizado por Carone. Trata-se, aliás, de eleição vocabular semelhante à cumprida pela maioria das traduções brasileiras e portuguesas da novela ${ }^{3}$, embora, dentre elas, encontremos também, em lugar de monstruoso, desde opções que desse sentido se aproximam, como grotesco, até adjetivos dimensionais adjacentes ao seu significado original, tais quais gigantesco e enorme. Por outro lado, a mais recente, que Celso Donizete Cruz realiza para a editora Hedra em 2009, abrindo quiçá um novo viés para a percepção da obra kafkiana na cultura de língua portuguesa, utiliza um sintagma mais distinto semanticamente dos seus predecessores: insuportável inseto - preferência que, ao lançar mão de um adjetivo profundamente focado na subjetividade dos que o rodeiam e não em uma imagem descritiva mais objetiva do protagonista, condiz com o projeto do tradutor de priorizar, defende-se que por fidelidade ao sentido do próprio texto original e da poética de Kafka, não a ocorrência fantástica em si - a transformação — mas consequências sociais suas.

Por tudo isso, seria apenas circunstancial que considerássemos Samsa uma monstruosidade em razão do uso dessa palavra, que lhe é etimologicamente próxima, na maior parte das traduções em língua portuguesa. Antes, fiamo-nos na evidência de que Samsa transformara-se num ser cuja definição passa justamente por termos como os que Julio Jeha, em análise diacrônica do vocábulo monstro, elenca: "um prodígio", "uma criatura meio humana, meio animal", "um desvio do que nela [a natureza] usualmente ocorria", "pessoa desfigurada", "ser malformado"4. E, especialmente, consideramos o fato de o personagem 
tornar-se algo dessemelhante à sociedade pequeno-burguesa de que fazia parte até então na qualidade de caixeiro-viajante que exerce a função de sustentar o seu círculo familiar, a qual não poderá mais cumprir, tornando-se assim, do ponto de vista social, não mais um mesmo mas um outro (que se difere socialmente dos traços padronizados do meio em que está inserido, isto é, que surge de uma radical ruptura com o que George Herbert Mead, filósofo americano da virada do século XIX para o XX, chamou de "outro generalizado", grupo social cujos membros são reconhecidos pela leitura em comum que fazem dos signos que o cercam e que, de certo modo, identifica-se com aquele Outro que Lacan grafa com maiúscula, nomenclatura a que ainda faremos menção). Nesse sentido, a tradução de Donizete Cruz, ao classificar o inseto em que Samsa metamorfoseara-se como insuportável a essa mesma comunidade (a que, afinal, ele não será mais comum, com que não mais comungará de uma mesma compreensão de mundo nem das mesmas reações ordinárias), curiosamente nos parece capaz de demonstrar sua monstruosidade com maior precisão do que os adjetivos pelo qual optam outros diversos tradutores.

Ora, como bem aponta José Gil, “o homem procura nos monstros, por contraste, uma imagem estável de si mesmo". Assim é que, por consequência, haverá, inclusive nas esferas das artes, profunda relação entre o monstruoso e a representação do outro (enquanto, na verdade, alter ego). A monstruosidade é a "forma extrema de alteridade", segundo enfatiza o especialista em cinema Luiz Nazário, porque "o monstro é a diferença feita carne" , conforme conclui Jeffrey Jerome Cohen — seja um outro coletivo ou originário de uma coletividade externa (todo um povo julgado como incivilizado, por exemplo) ou um outro individual que, originalmente mesmo, se abastarda totalmente do seio dessa civilização (aquele que se exclui / é excluído da sociedade de que origina por comportamentos classificados como ilegais ou imorais ou anormais). Por fim, trata-se da "ideia do monstro e a sua ligação com as noções do bárbaro e do selvagem"» e "como referência a todo ser que morfológica ou culturalmente se distinga das normas estéticas ou éticas vigentes", como complementa Célia Magalhães, investigadora das marcas do monstruoso na literatura. Diz-nos também Héctor Santiesteban:

El monstruo es metáfora; un ser llevado a otra forma, a otra existencia, pero en esencia el mismo; es el mismo, pero transportado a lo otro; de ahí la sensación de otredad que experimentamos con el monstruo. [...] Ese llevar a otra forma es llevar a otro ser. Por ello es que sentimos esa sensación de otredad asombrosa. Lo monstruoso es lo otro; es lo ajeno a nosotros. ${ }^{10}$
5. "Metafenomenologia da monstruosidade: o devirmonstro". GIL, José. Pedagogia dos monstros - os prazeres e os perigos da confusão de fronteiras, 2000, 176.

6. NAZÁRIO, Luiz. Da naturez̧a dos monstros, 1998, p. 29.

7. "A cultura dos monstros: sete teses". COHEN, Jeffrey Jerome. Pedagogia dos monstros - os prazeres e os perigos da confusão de fronteiras, 2000, p. 32.

8. MAGALHÃES, Célia. Os monstros e a questão racial na narrativa modernista brasileira, 2003, p. 23.

9. Ibidem, p. 26.

10. "El monstruo y su ser". SANTIESTEBAN, Héctor. Relaciones, 2000, p. 99. 
11. MAGALHÃES, Célia.

Os monstros e a questão racial na narrativa modernista brasileira, 2003, p. 32.
12. "Anotações sobre Kafka". ADORNO, Theodor. Prismas crítica cultural e sociedade, 1998 , p. 243.
Dessa forma, o aspecto sublinhado pela opção adjetival do tradutor Donizete Cruz, a qual enfatiza o quanto a sociedade julga o personagem kafkiano insuportável, seria o da incapacidade de essa mesma sociedade exercer um dialético discurso de alteridade em relação a Samsa, cuja condição absoluta de outro surge revelada em seu novo aspecto monstruoso.

Célia Magalhães lembra-nos ainda que, por exemplo, “em Frankenstein, a fonte de ameaça e de alteridade está no mesmo que se torna outro através de uma metamorfose autogerativa, ou seja, da autoalienação do sujeito e da multiplicação consequente de identidades" ${ }^{\prime 1}$. Ao contrário do que parece, essa citação nossa não é fortuita. Se buscássemos algum traço de hereditariedade na análise genética da monstruosidade em Samsa, quiçá aqui encontrássemos vestígios do DNA dessa marcante figura do gótico europeu oitocentista. $\mathrm{O}$ referido desdobramento identitário refere-se, é claro, ao fato de a criatura ser formada por várias partes de corpos de origens diversas, imagem que colabora para a construção de um discurso que revela o temor da sociedade de seu tempo (e não só, lamentavelmente, tendo mesmo essa discussão um infeliz caráter atual, inclusive na Europa) do sincretismo racial e cultural, interpretado como uma degeneração: ora, tal degeneração trata-se precisamente do mesmo que se torna outro, a partir desse processo de contaminação. Mas não é exatamente esse o gene que enxergamos se manifestar com veemência na novela kafkiana e sim o anterior: a autoalienação do sujeito resultado de uma metamorfose autogerativa. Samsa, de fato, em razão de sua transmutação em inseto - que Gilles Deleuze e Félix Guattari, no meritório ensaio sobre o autor intitulado Kafka - para uma literatura menor, identificaram com um movimento de devir-animal — perde, na destruição da sua familiaridade física com os demais membros do meio social em que se encontra, esse outro generalizado de que já fizera parte, sua utilidade perante essa mesma sociedade, o que configura a sua metamorfose em outro, um outro deveras insuportável. Mas uma questão, ao menos, surge de modo significativamente distinta em Kafka em relação ao seu antecessor do século XIX: a absoluta falta de espanto no que diz respeito ao surgimento do monstro, a tornar esse outro, ex-mesmo (ou até então suposto mesmo apenas, como defenderemos), figura na verdade natural, ou naturalizada, ainda que bastante incômoda - daí a importância de, desde o instante inicial da novela, a metamorfose já estar consumada. Theodor Adorno, muito a propósito, reconhece que, em Kafka, "não é o monstruoso que choca, mas sua naturalidade"12. Frankenstein, de certo modo, corrobora o discurso de que o sincretismo cultural representa um fator de corrupção social; $A$ metamorfose, pelo contrário, evidencia (denunciando a necessidade de que seja reconhecido) o devir-monstro que cada um abriga dentro de si 
oculto sob a máscara de uma identidade alienada, entendendo aqui por alienação a autorrepresentação não através de significantes seus mas daqueles que se originam apenas nos outros: ou seja, a novela intui ter por base o processo por que teria passado Samsa ao tornar-se o mesmo de outros perdendo assim o seu próprio en, o qual, todavia, surge-nos repentinamente reencontrado na metamorfose ocorrida pouco antes do início da narrativa e cujo efeito testemunhamos no seu período inaugural.

Em Samsa, pois, concluímos que se representa uma subjetividade que, a despeito de sua existência, o homem não reconheceria em si mesmo e surge de súbito delatada na narrativa, condição de outro social que, com efeito, vem dessa forma se revelar para ele mesmo - e, por consequência, para os leitores que com ele potencialmente se identifiquem: "Os monstros, felizmente, existem não para nos mostrar o que não somos, mas o que poderíamos ser. Entre estes dois pólos, entre uma possibilidade negativa e um acaso possível, tentamos situar a nossa humanidade de homens"13, como aponta José Gil. Assim, nessa sociedade em que uma identidade geral é forjada por vetores externos e a subjetividade é alienada na vã tentativa de nos poupar da segregação, o devir-monstro desse herói kafkiano, o inseto que inadvertidamente lhe vaza, que desavisadamente lhe escapa, seria a exibição da sua verdadeira natureza, o que o isola do comum, a qual até então fora mantida solapada tão somente por uma necessidade de integração civil. Conforme reconhece por fim Donizete Cruz: "Ele [Samsa] só toma consciência de sua alienação ao ser alienado de sua forma humana. Não é o fato de se transformar em inseto o que o aliena, isso só lhe revela sua real alienação"14. E se, como sublinha Michel Foucault em suas aulas sobre a anormalidade (referindo-se a, por assim dizer, monstros reais) observada entre os séculos XVII e XIX, "o monstro é, por definição, uma exceção" 15 , a monstruosidade de Samsa não habita propriamente nessa sua natureza animal mas na singular (e por isso inesperada; mais do que isso: a todos insuportável) manifestação dessa mesma natureza. Teriam sentido análogo as palavras de Adorno: "A individuação tornou-se tão difícil para os homens, e é ainda hoje tão incerta, que eles são tomados por um susto mortal assim que se levanta um pouco o seu véu"16.

Em suma, a novela constrói não simplesmente a metamorfose do mesmo em outro, mas, de modo mais preciso, a de um suposto mesmo cuja identidade totalmente alienada fora apenas socialmente fraudada (os "homens fabricados em linhas de produção" ${ }^{17}$ identificados por Adorno) em seu verdadeiro e até então oculto outro - figura in-comum à sua pretensa comunidade. Ora, se Lacan vê, do ponto de vista psicanalítico, a formação do eu a partir da sua interação com outros ${ }^{18}$ - o pequeno outro, que nada mais é que o eu visto como outro a partir da fase da
13. "Metafenomenologia da monstruosidade: o devirmonstro”. GIL, José. Pedagogia dos monstros - os prazeres e os perigos da confusão de fronteiras, 2000, 168.

14. "Introdução”. CRUZ, Celso Donizete. A metamorfose, 2009 , p. 21-2.

15. FOUCAULT, Michel. Os anormais: curso no Collège de France (1974 - 1975), 2001, p. 72.

16. "Anotações sobre Kafka". ADORNO, Theodor. Prismas crítica cultural e sociedade, 1998, p. 249 .

\section{Idibem.}

18. "O eu é referente ao outro. $\mathrm{O}$ eu se constitui em relação ao outro. Ele é o seu correlato". LACAN, Jacques. O seminário livro 1: os escritos técnicos de Freud, 1979 , p.63. 
19. Sobre isso, lembra-nos Antonio Quinet: "Eis o engodo do imaginário: o sujeito desconhece que o outro é a projeção de seu eu ideal e, para se livrar de sua menos-valia em relação a ele, entra numa luta de puro prestígio com ele. Esse outro que é meu próximo é minha alteridade egoica, projeção narcísica de meu eu, espelho que me envia minha própria imagem a ponto de considerá-la semelhante. Este outro, se é alter, é alter ego, nada mais do que meu ego alterado. Trata-se aqui de um outro egoico". QUINET, Antonio. Os outros em Lacan, 2012, 55.

20. DELEUZE, Gilles; GUATTARI, Félix. Kafka - para uma literatura menor, 2002, p. 36.

21. NAZÁRIO, Luiz. Da natureza dos monstros, 1998, p. 40.

22. "Anotações sobre Kafka". ADORNO, Theodor. Prismas crítica cultural e sociedade, 1998, p. 249. infância do estágio do espelho e, em consequência disso, do outro que passa a ser visto como $e u^{19}$; e o grande Outro, referência que permite delimitar o sujeito, o qual é, por sua vez, uma entidade sem identidade que apenas é momentaneamente constituída em função necessariamente de sua relação com o Outro - sendo, assim, o processo de alienação incontornável na construção da subjetividade; é verdade também que a vertente patológica desse processo residirá na incapacidade de o sujeito desalienar-se dos significantes que o Outro, como lugar do inconsciente, impõe-lhe através da linguagem, abdicando de deslizamentos nessa sua experiência objetiva, estando assim aprisionado a desempenhar os papéis que lhe são imputados socialmente. Deleuze e Guattari, por sua vez, nos indicam que "todo o devir-animal de Gregório, o seu devir coleóptero, besouro, escaravelho, barata, é que traça a linha de fuga intensa em relação ao triângulo familiar, mas, sobretudo, em relação ao triângulo burocrático e comercial" ". Por isso: "A metamorfose, de Franz Kafka, é o mais perfeito relato de uma autodepreciação gerada socialmente - a monstruosidade como um sentimento da alma"21, conforme reconhece Nazário. Daí por fim que, citando uma vez mais Adorno: "A gênese social do indivíduo revela-se no final como o poder que o aniquila. A obra de Kafka é uma tentativa de absorver isso" "22. Tal alienação social verificada desde o século anterior é, segundo uma visão marxista, fruto da lógica em que se pauta a organização da população em grandes metrópoles após as Revoluções Francesa e Industriais e do imperativo cada vez mais premente de construir sociedades de consumo com gostos assemelhados e necessidades idênticas, de modo a tornar rentável a produção em série de produtos. Determinados exercícios de alteridade, portanto, contrariariam razões de ordem desenvolvimentista e econômica. Dado que esse processo potencializa-se no decorrer dos anos 1900, tornando-se uma questão do homem da sociedade contemporânea pertinente a ser investigada, a influência kafkiana se fez sentir por toda a literatura ocidental do século XX, em razão da efetividade do método de representação-denúncia dessa condição empreendido por Kafka.

É preciso dizer que, por isso mesmo, o uso do adjetivo kafkiano não se dará nunca impunemente. Em função das características muito particulares da obra do escritor tcheco, o termo está hoje carregado de significados que ultrapassam os sentidos imediatos fornecidos pelos dicionários que poderiam, restritamente a princípio, permitir o seu emprego em contextos em que se referisse a algo como "relativo a Kafka" ou "aquele que é admirador de Kafka ou conhecedor de sua obra", por exemplo. Modesto Carone, ao identificar nos seus personagens as angústias sofridas pelo homem moderno habitante das sociedades de controle (foucaultianamente falando), define que 
a rigor é kafkiana a situação de impotência do indivíduo moderno que se vê às voltas com um superpoder (Übermacht) que controla sua vida sem que ele ache uma saída para essa versão planetária da alienação — a impossibilidade de moldar seu destino segundo uma vontade livre de constrangimentos, o que transforma todos os esforços que faz num padrão de iniciativas inúteis. ${ }^{23}$

A propósito desse assunto, Durval Muniz de Albuquerque Júnior explica:

Kafka foi muitas vezes acusado de desenhar estruturas, pensar mundos dos quais suas personagens não poderiam escapar, em que são apenas objetos passivos e não sujeitos ativos. Foi cunhado, inclusive, o adjetivo kafkiano para se referir a estes mundos que parecem nascidos de pesadelos, que parecem absurdos por discreparem do mundo cotidiano e rotineiro, por nascerem de uma ruptura inesperada com a ordem, por serem excepcionais, bizarros, grotescos, por mergulharem suas personagens em sucessivas situações das quais não conhecem as motivações, que não conseguem explicar racionalmente e das quais não conseguem escapar, embora elas possuam uma lógica própria, difícil de dominar. ${ }^{24}$

\section{E Edson Passetti também reflete:}

Com Kafka apareceu a palavra kafkiano, uma designação para os excessos de racionalidades impessoais nas funções, cargos e procedimentos que orientam a produtividade moderna, suas construções de verdades amparadas em realidades e sonhos, envolvendo gentes e animais, surpreendentes instantes onde se espera o previsível. ${ }^{25}$

Sendo essa particular mimesis kafkiana algo inescapável em uma realidade que cada vez se aproxima mais destes mundos que parecem nascidos de pesadelos, com seus excessos de racionalidades impessoais, sua influência, reiteramos, será francamente verificada na literatura que lhe sobrevém, não sendo diferente, olhando de modo mais específico, com a ficção portuguesa. A fim de, por amostragem (e na inversão espaço-temporal do percurso crítico empreendido por Jorge Luis Borges em "Kafka e seus precursores"), evidenciar tal ascendência em seus predecessores portugueses, poderíamos citar a importante escritora, além de estudiosa da obra desse escritor, Agustina Bessa-Luís, que, especialmente nos contos do início da carreira literária, apresenta-se devedora de uma estética kafkiana, como aliás já verificamos em outra oportunidade ${ }^{26}$. Designadamente acerca da relação $\operatorname{com} A$ metamorfose, resgataríamos também a leitura ficcional que Alfredo Margarido realiza da novela com o seu romance $A$ centopeia de 1961 (já após ter encontrado Kafka em No fundo deste canal,
23. CARONE, Modesto. Lições

de Kafkea. 2009, p. 100.

24. "No castelo da história só há processos e metamorfoses, sem veredicto final".

ALBUQUERQUE JÚNIOR,

Durval Muniz de. Kafkea, Foucault: sem medos, 2004, p. 17.

25. "Foucault-Kafka, sem medos”. PASSETTTI, Edson. Kafka, Foucault: sem medos, 2004, p. 10.

26. A propósito disso, verificar nosso artigo "Como apalpar o impalpável?! Leitura intertextual do conto kafkiano "A Pousada", de Agustina Bessa-Luís", publicado no número $22 \mathrm{da}$ Revista Veredas, da Associação Internacional de Lusitanistas, em 2014. 
27. GUERRA, Álvaro. Memória, 1971, p. 82.

\section{Ibidem.}

29. Com indubitável sucesso à época de seu lançamento, em 1968, a despeito mesmo de um caráter que poderíamos declarar livremente como de um embuste sensacionalista, é inaudito que identifiquemos a influência dessa obra em produções artísticas diversas, inclusive no cinema, desde o seu contemporâneo 2001 - uma odisseia no espaço (e não deixa dúvidas quanto a isso a cena em que a evolução dos primatas para a condição de humanos, no prólogo da película intitulado "A aurora do homem", se dá por influência de um monolito, que mais tarde se revela um artefato alienígena) até o filme de Steven Spielberg E. T. - o extraterrestre (1982), no qual uma das cenas finais, em que $o$ garoto Elliott toca os dedos do personagem de outro planeta, ao reproduzir $A$ criação de Adão, célebre afresco de Michelangelo pintado no teto da Capela Cistina, coloca-o na mesma posição do homem, enquanto fornece à figura do extraterrestre justamente o status do Deus, que, na obra renascentista italiana, está, enfatizemos, justamente no exercício da sua atividade criadora. publicação do ano anterior). Mas, interessados que somos sobretudo pelo gênero conto, duas outras breves narrativas despertariam nossa atenção inicial, ao evidenciarem marcas dessa vertente kafkiana e mais diretamente dialogarem com a novela tcheca: "O cavalo branco" de Álvaro Guerra e "Doenças de pele" de Herberto Helder.

Apresentado em Memória, livro de 1971, "O cavalo branco" (curtíssimo conto, desenvolvido mesmo em um só parágrafo, dotado de um ritmo que acelera a partida de xadrez que nele se opera) foi recolhido mais tarde na Antologia do conto fantástico português em que E. M. de Melo e Castro compila narrativas oitocentistas e novecentistas do gênero, com a primeira edição em 1965 e uma segunda ampliada em 1974. No conto de Álvaro Guerra, um homem, o narrador, se descobre, enquanto pensa no referido jogo, transformado na peça que dá título à narrativa, de modo que, consequentemente, a sala de sua casa torna-se o tabuleiro do jogo. Aqui, seu devir-animal é potencializado pelo caráter inanimado desse cavalo, fazendo com que o processo evolua para uma absoluta reificação. Sua reação diante da metamorfose, no entanto, coaduna com a transitoriedade desse sentimento de espanto, marca da poética kafkiana e, por consequência, da narrativa fantástica novecentista que Kafka, afinal, inaugurara: "logo o meu espanto foi substituído por agudo interesse na localização das outras pedras, nas perspectivas do jogo"27. A mão que o maneja (e literalmente, então, o manipula), descrita como "mole, viscosa, fria, esverdeada, de longos e descarnados dedos, impossível de identificar com mão de homem ou mulher" ${ }^{28}$, associa-se com a imagem vulgarmente atribuída a seres extraterrestres (à época identificados como marcianos, os monstros do espaço, por isso chamados alienígenas, os aliens, isto é, os outros). Em se tratando de um conto de 1971, é possível que essa identificação se relacionasse aqui com a teoria de que eram os deuses astronautas, muito em voga no tempo da publicação do conto, difundida pelo livro do suíço Erick von Däniken sob rigor científico duvidoso (para dizer o mínimo), a qual expõe a possibilidade de que antigas civilizações terrestres ter-se-iam desenvolvido sob o fomento de extraterrestres ${ }^{29}$. Independente de quem literalmente o controla — um ente extraterreno de raça superior ou uma divindade - do ponto de vista metafórico o que temos aí representados são os idênticos vetores sociais de controle que, no caso de Gregor Samsa, mantinham-no sob a forjada forma humana anterior à narrativa da novela. Em "O cavalo branco", não por acaso ameaça o personagem metamorfoseado no tabuleiro uma torre e um bispo negros, representantes, respectivamente, do panoptismo das sociedades de controle de que nos fala Foucault e das instituições religiosas. Assim, promove-se a denúncia da condição de um homem que, 
mesmo não pertencendo às esferas mais baixas da segmentação social (não chegava a ser um peão, primeira peça de que o jogador em sua estratégia abre mão, antes identificando-se com um representante da classe média, oriundo portanto da mesma esfera pequeno-burguesa descrita por Kafka), revela a falta de importância de suas aspirações pessoais e o seu papel francamente utilitarista dentro da sociedade competitiva em que se insere, baseada na meritocracia que a hierarquia das peças do jogo não permite olvidar, já que será então sacrificado por motivo banal, "por causa de um xeque ao rei que nem sequer seria xeque-mate" 30 - descartado, portanto, como fora Samsa ao fim da novela que protagoniza.

Além disso, também em diálogo com a narrativa de Kafka, uma grande preocupação do narrador-personagem será a reação de sua esposa caso o flagrasse naquela circunstância, ao adentrar a sala-tabuleiro: "como ela ficaria zangada ao ver-me assim transformado em cavalo branco" 31 . Quando ela entra em cena, todavia, permanece "alheia ao que estava a se passar" 32 , não percebendo a transformação e disparando comentários sobre o que falara ao telefone por longo tempo, como cotidianamente fazia, notícias comezinhas alheias, o que dá à vulgaridade do protagonista não apenas uma dimensão sócio-política, mas também pessoal: "Eu era um cavalo branco fora do jogo e ela continuava a tratar-me como se eu fosse o seu marido" ${ }^{33}$. "O cavalo branco", em sua estrutura fantástica, é assim revelação realística e niilista da insignificância do indivíduo quando comparado ao chamado bem comum e da mediocridade imposta à vida do cidadão médio.

Em nossa identificação do kafkiano na literatura portuguesa, são dignas de nota as, também narradas em primeira pessoa, nódoas brancas que vão gradativamente (da ponta do dedo a todo o corpo) tomando o herói do herbertiano "Doenças de pele", conto publicado pouco antes, em 1960, no volume Os passos em volta ${ }^{34}$. Nele, o protagonista vai igualmente se transmudar, não em inseto, mas em uma espécie de réptil branco. O enredo recebe tratamento semelhante ao instituído pela poética de Kafka, sobretudo em razão de, conforme ocorre em $A$ metamorfose, o narrador não procurar explicações para o fenômeno, já que "cada vez menos desejava saber se era uma doença, ou que doença era" ${ }^{35}$, preocupando-se mais detidamente com os resultados sociais daí advindos. As transformações sofridas pelo herói, assim, não se limitam ao aspecto físico. Ele, por exemplo, antes "não amava ninguém" 36 ainda que convivesse com muita gente: "Era um homem coordenado com os dias, entendendo que a matéria da minha existência, doce e dócil, afrontava a matéria do mundo e se amansava nos dedos desse mundo" ${ }^{37}$. Uma vez, porém, que precisasse se esconder do restante da sociedade
30. GUERRA, Álvaro. Memória, 1971, p. 83.

31. Ibidem, p. 82 .

32. Ibidem, p. 83.

33. Ibidem.

34. Esse livro de Herberto Helder, aliás, apresenta outros textos que, por motivos diferentes, poderiam ser lidos sob uma ótica como a inaugurada e difundida por Kafka. Citaríamos "O celacanto", em que um homem, após ler uma monografia a respeito do assunto, abandona sua cidade em busca de um estranho peixe (que dá nome ao conto) que muitos criam extinto. Trata-se de um texto kafkiano tanto pela forma estilizada como o personagem é batizado - KZ, conforme $\mathrm{K}$. de O Castelo ou Joseph K. de O processo - quanto pela sua ocupação de funcionário público do ministério das finanças da cidade. Essa profissão, ícone da obra do autor tcheco (também exercida por ele próprio), surge em razão do seu compromisso com a burocracia (em seu julgamento generalista do mundo a despeito das peculiaridades do ser humano): novamente, os excessos de racionalidades impessoais nas funções, cargos e procedimentos que orientam a produtividade moderna a que se refere Passetti.

35. HELDER, Herberto.

Os passos em volta, 2005, p. 64.

36. Ibidem, p. 61.

37. Ibidem, p. 63. 
38. Ibidem, p. 66.

39. "El monstruo y su ser". SANTIESTEBAN, Héctor. Relaciones, 2000, p. 126.

40. SARAMAGO, José. Objecto quase, 2004, p. 37.

41. Ibidem, p. 39.

42. Ibidem, p. 39 para ocultar o estranho problema, e na angústia da perda definitiva do direito de convivência, aproximava-se cada vez mais das pessoas enquanto podia disfarçar suas diferenças com luvas ou outras vestimentas, ao mesmo tempo em que o seu amor por elas surgia e crescia intensamente.

Não fazer parte da comunidade dita humana, por conseguinte, será curiosa e paradoxalmente aproximar-se de valores reconhecidamente humanos por discursos que, em verdade, não são efetivamente praticados, o que denuncia a condição reificada do homem contemporâneo - essa metamorfose, afinal, constrói, nesse devir-animal, criatura mais humana do que a humanidade. Daí que, na última cena, o protagonista se observe nu no quarto escuro e, afinal completamente só, reconheça-se em um mundo alternativo que se identifica com a fundura do espelho: "lá dentro"38 da superfície vítrea, como enfatiza, a sugerir que esse espaço outro (ou, muito a propósito, do outro lacaniano) encontra-se justamente nele mesmo, a representar uma profunda consciência da sua própria condição e da condição humana a partir do seu aspecto monstruoso: "el monstruo es, en cierto sentido, espejo del hombre"39, segundo Santiesteban. E, na poética da prosa herbertiana que sempre se confunde com o da poesia, tal revelação acerca das relações de alteridade mune de uma dimensão psicológica o drama do personagem, que já não pertence à sociedade vigente, ex-mesmo que se metamorfoseia em outro em relação ao Outro ou ao outro generaliz̧ado, quiçá exemplar último da raça humana.

Esses dois exemplos, porém, surgem-nos aqui com a função retórica de nos encaminhar, sem que pareça (porque não seria mesmo verdade, como demonstramos) que tenha surgido de modo isolado na cultura portuguesa essa influência de Kafka na prosa de José Saramago, à narrativa "Embargo" - conto publicado originalmente em 1974 e que, logo depois, comporia o livro Objecto quase, que o autor lançou em 1978, antes portanto de ele tornar-se o afamado romancista da série iniciada em 1980 por Levantado do chão. Nessa narrativa, cujo enredo foi adaptado para o cinema em 2010 em longa-metragem homônimo de António Ferreira, um evento fantástico acomete o protagonista no momento a princípio banal em que ele conduz o seu automóvel rumo ao trabalho. Aquilo que, no conto, seria inicialmente apenas um sugestivo discurso de sentido figurado - o que se evidencia no fato de que o carro "respondia aos seus movimentos como se fosse um prolongamento mecânico do seu próprio corpo"40 — logo se concretiza em uma autêntica simbiose entre o condutor e o seu veículo, já que, em um dado momento, o homem "não foi capaz de sair" tas aderiam ao encosto do banco [...] como um membro adere ao corpo" ${ }^{\prime 2}$. O herói sofre, assim, efetiva transformação, certa 
sorte de mutação que lhe subtrairá os traços humanos para progressivamente o reificar, enquanto, em sentido oposto, o carro ganha qualidades mais humanas, como a de tomar decisões próprias, dando mesmo nova dimensão semântica ao prefixo de automóvel.

O que o personagem do conto saramaguiano vive então é uma espécie de metamorfose, tema universal da arte literária que, a partir do século XX, será inescapável e essencialmente, nos termos já antes discutidos, kafkiano. É Perfecto Cuadrado quem sugere, em breve análise, a natureza kafkiana de "Embargo":

Parece imperativa a dupla referência a uma muito ibérica e barroca tradição de bumor negro e ao que poderíamos chamar o absurdo friamente racional, cujo paradigma seria a narrativa kafkiana, conjugados ambos na transformação lenta e minuciosa de um instante de banalidade quotidiana numa eternidade de excepcionalidade monstruosa, como evidente é também o protagonismo decisivo da cidade como espaço coadjuvante dessa transformação, uma cidade labiríntica [...]. Um automobilista anónimo num carro qualquer duma cidade sem perfis nem marcas identificadoras, comodamente instalado na sua rotina quotidiana, um acontecimento surpreendente primeiro, preocupante e ameaçador depois, finalmente fatal, um kafkiano ir acontecendo o que nunca acontecera, mas que se demonstra acontecivel: o arranque, em certa medida, de Ensaio sobre a cegueira. ${ }^{43}$

Assim é que o episódio narrado em "Embargo" traz uma verdade que se ampara em realidade e sonho de que nos fala Edson Passetti em sua visão a respeito do kafkiano. A verdade construida pelo espaço ficcional referida ainda por Passetti habita, no conto de Saramago, a questão da desumanização do homem, a sua monstruosa reificação consequente do protagonismo assumido pelo objeto que deveria estar, pelo contrário, ao seu serviço — seu reposicionamento, portanto, como objeto passivo e não sujeito ativo, conforme definira Muniz de Albuquerque ao discursar sobre o mesmo assunto - denúncia que perpassa todo o livro Objecto quase ${ }^{44}$, dando forma nessa sua segunda narrativa a uma espécie de jogo metafórico que no texto se desenvolve de modo concreto, a partir da metamorfose fantástica do homem em automóvel ou, antes, da simbiose que estabelece com o seu veículo. Ratificando tal ideia, a leitura de Maria Alzira Seixo propõe que esse conto é símbolo "da escravização e destruição do homem pelo objecto, ou melhor, da sua identificação com ele" 45 , leitura com que concorda Horácio Costa, para quem "Embargo", "vignette sobre a situação de dependência imposta ao homem contemporâneo pelas técnicas de reprodução da sociedade de consumo [...], ilustra a 'servidão' do sujeito tornado objeto"46

Tal inversão sujeito-objeto insere o conto na lista de obras cuja exegese descobre o mesmo "princípio da subjetividade
43. "Objecto quase e o estatuto das obras menores". CUADRADO, Perfecto. Das possibilidades do impossivel, 1997, p. 46-7.

44. Sobre o título da coletânea, já desenvolvemos anteriormente a seguinte análise: "Porque, afinal, o ponto de vista desta e das demais narrativas poderia ser o material e não o humano (antes o automóvel do que seu condutor, antes a cadeira do que seu ditador, antes os mortos do que seu soberano rei, antes o cavalo do que a sua parte humana formadora do Centauro [...]), deparamo-nos com o hipérbato que compõe o título: não mais quase objeto (parte da expressão bomem quase objeto, em que ‘homem' exerceria a função nominativa) mas sim objeto quase (parte da expressão objeto quase homem, o que promove o objeto à posição de sujeito)". "Coisas de Saramago". SOARES,

Marcelo Pacheco. Avanços em Literatura e Cultura Portuguesas Século XX. Vol. 1, 2012, p. 163 - e acrescentaríamos agora: temos, por consequência, a transferência do sujeito para a posição de objeto e, ademais, um objeto elíptico, reiterando o seu apagamento: Objecto quase Ø.

45. "Recensão crítica a Objecto quase, de José Saramago".

SEIXO, Alzira. Colóquio/Letras, 1979, p. 78.

46. "Alegorias da desconstrução urbana: The memoirs of a survivor, de Doris Lessing, e Ensaio sobre a cegueira, de José Saramago". COSTA, Horácio. José Saramago uma homenagem, 1999, p. 139. 
47. "Anotações sobre Kafka". ADORNO, Theodor. Prismas crítica cultural e sociedade, 1998 , p. 258.

48. "Alegorias da desconstrução urbana: The memoirs of a survivor, de Doris Lessing, e Ensaio sobre a cegueira, de José Saramago". COSTA, Horácio. José Saramago uma homenagem, 1999, p. 139.

49. SARAMAGO, José. Objecto quase, 2004, p. 33.

50. KAFKA, Franz. $A$ metamorfose, 2006, p. 13. (grifo nosso) completamente alienada" ${ }^{47}$ que Theodor W. Adorno identifica precisamente em Kafka - aqui, uma alienação coisificada, a identidade humana a se reduzir a objeto, processo que o filósofo alemão encontrara na citada imagem dos homens fabricados em linhas de produção. E essa leitura certamente se potencializa em função do plano de fundo da narrativa, composto a partir de um contexto político real e contemporâneo à sua escrita, o da crise do petróleo do início da década de 1970 causada pelo controle do escoamento da produção imposta pelos fornecedores árabes, o que comprometeu o abastecimento de combustíveis na Europa, atingindo parte importante do modus operandi da sociedade ocidental. Eis, por fim, o outro amparo da verdade, desta feita mais designadamente na realidade de um fato histórico, que afinal é a primeira motivação para o título do conto, cuja ambiguidade é ressaltada ainda por Horácio Costa quando aponta que "é o chofer de classe média, um exemplo acabado de cidadão comum, quem é 'embargado' por seu automóvel"48 — sendo o protagonista do conto, portanto, novamente em termos lacanianos, embargado pelo Outro, eu de identidade interditada tornado apenas, naquele contexto, um sujeito-motorista.

Mas, para além da temática metamórfica de "Embargo", seria curioso observar com maior atenção outros semas do conto saramaguiano em análise, de valor estrutural, que nos permitem comprovar a sua aproximação à novela de Kafka. No início do conto, por exemplo, aplica-se uma técnica também empregada pelo escritor tcheco em seus dois principais textos: A metamorfose e $O$ processo. Coibindo a tentação dos leitores de adotarem o recurso fácil de encarar suas narrativas como um sonho, Kafka estrategicamente inicia ambas por cenas em que o protagonista está precisamente despertando de seu sono, indiciando que tudo sucederia, a partir de então, sob um estado de vigília de seus heróis. A crítica nem sempre terá percebido o estratagema, o que levou a cansativos equívocos de interpretação de sua obra, não raras vezes associada de modo reducionista à atmosfera onírica para explicar a sua irrealidade.

Nesse sentido, surge aqui um fator de legitimação de nossa leitura comparativa e que fica a cargo do cotejamento dos trechos iniciais das duas obras: o de "Embargo" — "Acordou com a sensação aguda de um sonho degolado" muito semelhante frase inaugural da novela de Franz Kafka — "Quando certa manhã Gregor Samsa acordou de sonhos intranquilos, encontrou-se em sua cama metamorfoseado num inseto monstruoso" ${ }^{50}$ — segundo, reiteremos, a tradução de Modesto Carone, mas cujas versões portuguesas não apresentarão diferenças significativas que invalidem a comparação, não apenas no uso do adjetivo monstruoso, como já averiguamos, mas também, importante nesse momento, nas variações possíveis para 
unrubigen Träumen, que se apresentam em edições do país como sonhos inquietos ou inquietantes ou sonho agitado, fazendo mesmo do sonho degolado por que opta Saramago uma nova possibilidade de tradução, quiçá mais dramática. É claro que seria possível levantar essa hipótese (que justamente tentamos descartar), a de que a narrativa de "Embargo" se desenvolve em um sonho, em razão do uso da imagem do casulo para se referir tanto ao leito do casal - "o casulo morno que era a cama" 51 — quanto ao carro "aquele casulo quente e embaciado que o isolava do mundo" 52 . No entanto, a reiteração do signo é antes mais uma evidenciação do diálogo do conto com a novela de Kafka (já que é em um inseto que Samsa se metamorfoseara, campo semântico de que também faz parte o vocábulo casulo escolhido) do que uma analogia de que estar no automóvel fosse como dormir no leito.

Temos assim configurado, desde a sua oração inicial, o sintoma de que haverá algo de kafkiano em "Embargo", ainda antes de se conhecer o seu enredo. E tal fato consiste na revelação da monstruosidade do protagonista do conto, que migrará assim de sua condição de mesmo de identidade alienada, como tantos assalariados da pequena-burguesia citadina contemporânea, em outro cuja alienação torna-se demasiadamente (ou monstruosamente, ou ainda insuportavelmente) evidenciada na concretização fantástica da superdependência do cidadão de seu veículo particular. Seu único destino possível será, portanto, a (auto)segregação verificada no temor do protagonista de ser visto na sua nova forma monstruosa, exposto como nos freak shows de meados dos séculos XIX ao XX e, mais cedo, nos manicômios de séculos passados ${ }^{53}$, de tal modo que lhe preocupa "imaginar-se rodeado de gente, o retrato nos jornais, a vergonha de ter urinado pelas pernas abaixo" 54 . Isso é que lhe motiva a fuga para ambientes suburbanos e, mais radicalmente ao fim da narrativa, para fora da cidade (para uma paisagem composta somente por pedras, serra e um céu espantosamente baixo): porque não pertence mais à lógica que rege o espaço citadino. Mas os reais motivos dessa cisão, dessa inevitável segregação, ainda abordaremos mais à frente.

Atenhamo-nos agora a alguma análise teratológica do personagem. A monstruosidade dessa figura simbiótica vai se construindo linha a linha, ganhando contornos no decorrer da narrativa, como o próprio automóvel que vai se construindo pouco a pouco em sua linha de montagem. E será no terço final do conto, em desespero em razão da insólita circunstância em que se vê então envolvido, que o estado grotesco do personagem tomado parte do objeto-carro estará demonstrado ainda mais francamente. Tal situação de degradação já é notável em trechos como aquele em que ele sente uma "irreprimível vontade de urinar [...], libertando interminável o líquido quente que vertia e
51. SARAMAGO, José. Objecto quase, 2004, p. 33.

52. Ibidem, p. 43.

53. Segundo Michel Foucault: "O hábito da Idade Média de mostrar os insanos era sem dúvida muito antigo. Em algumas das Narrtïrmer da Alemanha tinham sido abertas janelas gradeadas que permitiam observar, do lado de fora, os loucos que lá estavam. Constituíam eles, assim, um espetáculo às portas das cidades. Fato estranho é que esse costume não tenha desaparecido no momento em que se fechavam as portas dos asilos mas que, pelo contrário, ele se tenha desenvolvido, assumindo em Paris e em Londres um caráter quase institucional. Em 1815, ainda, a acreditar num relatório apresentado na Câmara dos Comuns, o hospital de Bethleem exibe os furiosos por um penny, todos os domingos. Ora, a renda anual dessas visitas elevava-se a 400 libras, o que pressupõe a cifra espantosamente alta de 96.000 visitas por ano. Na França, até a Revolução, o passeio por Bicêtre e o espetáculo dos grandes insanos continua a ser uma das distrações dominicais dos burgueses da rive gauche. Mirabeau relata em suas Observations d'un voyageur anglais que os loucos de Bicêtre eram mostrados 'como animais curiosos ao primeiro campônio que aceitava pagar um liard'. Vai-se ver o guardião mostrar os loucos como, na feira de Saint-Germain, o saltimbanco domador de macacos. Alguns carcereiros tinham grande reputação pela habilidade com que faziam os loucos executar passos de dança e acrobacias, ao preço de algumas chicotadas". FOUCAULT, Michael. História da loucura na Idade Clássica, 1978, p. 163-4. É dessa então longa tradição de exibição do monstruoso e da loucura que o personagem de "Embargo" deseja esquivar-se.

54. SARAMAGO, José. Objecto quase, 2004, p. 44. 
55. Ibidem, p. 42.

56. Ibidem, p. 42.

57. Ibidem, p. 45.

58. Ibidem, p. 45.

59. Ibidem, p. 45 .

60. Ibidem, p. 33.

61. Ibidem, p. 41. Grifo nosso. escorria entre as pernas para o piso do carro" 55 , a que se segue um choro baixo identificado a um "ganido" 56 , em uma imagem de perda da dignidade do ser humano muito semelhante, aliás, à situação a que serão submetidos os personagens de Ensaio sobre a cegueira duas décadas mais tarde. Mas se torna ainda mais manifesto o prejuízo à sua humanidade a espécie de duplo dessa cena, que se passa horas depois, porque, quando novamente tiver que urinar, o personagem já não encarará o fato com a mesma reação, já que, em seu devir-animal completado, estará "humilhado demais para se envergonhar" 57 . Nessa altura, o homem já se encontra a brincar com as palavras que lhe surgem pela ocasião, identificando então alguma desabilidade para lidar com a linguagem humana — "humilhado, himolhado"58: "Ia declinando sucessivamente, alterando as consoantes e vogais, num exercício inconsciente e obsessivo que o defendia da realidade" 59 . Por outro lado, é importante perceber que haverá nessa atitude algum importante, ainda que tardio, teor de resistência motivada pela tomada de consciência de sua condição reificada.

O carro, por sua vez, também se animiza, mas, para um ser dito inanimado, o processo, pelo contrário, é antes uma promoção, notadamente porque o bicho / monstro em que se transforma parece forte e poderoso, ao contrário da fragilidade que acomete o personagem, homem nitidamente fraco desde o início do conto, quando até mesmo falta-lhe "o ânimo para levantar-se, para fechar a janela" ${ }^{60}$. De herói ou protagonista do conto, portanto, o inominado (e assim já desde o início coisificado, elipticamente referido desde a primeira oração: $\varnothing$ Acordou com a sensação aguda de um sonho degolado) personagem de "Embargo", pouco a pouco vitimado por essa lei da selva que favorece aos mais fortes, tende a perder tal condição (ainda que, reiteremos, percebamos nele laivos de uma resistência, mesmo que improfícua), passando ao secundarismo de quem obedece ao carro (na inversão sujeito vs. objeto que analisamos desde o título do livro e no embargo que é do petróleo, historicamente, mas é também da vida humana), perdendo o controle sobre si na medida em que o carro assume a efetiva posição de condutor - dos caminhos a percorrer, do enredo a se desenvolver... no vácuo deixado pelo próprio homem - e então prontamente ocupado pela máquina — de espaços de decisão, de arbítrio. Quando, aliás, afirma-se que "ninguém nunca ficara preso desta maneira no seu próprio carro, pelo seu próprio carro" ${ }^{61}$, o sintagma final, ao se propor a substituir o anterior, faz migrar o automóvel sintaticamente da condição de mera menção locativa adjunta (no seu próprio carro) para a função de agente da passiva (pelo seu próprio carro), aquele que age portanto enquanto um sujeito sofre as consequências verbais da sentença — com o agravante de tal sujeito passivo aqui ser, além de tudo, semanticamente (ainda 
que não sintaticamente) indeterminado e esvaziado pelo pronome indefinido "ninguém".

Ora, quanto a isso, faz-se importante lembrar que, por toda a manhã, o personagem hesitara a respeito de que atitudes tomar, oscilara no tocante a que logradouro se dirigir: ir direto ao escritório ou visitar clientes; enquanto o automóvel parava em filas de postos de abastecimento com uma espécie de assertividade, eivada mesmo de agressividade, fundamentalmente humanas. Por isso mesmo, enquanto o homem desesperadamente tentava se libertar, "os limpa-vidros, que sem querer pusera em movimento no meio da agitação, oscilavam com um ruído seco, de metrônomo" ${ }^{62}$, como se o automóvel estivesse, até com algum nível de galhofa, a lhe fazer metaforicamente um gesto de negativa que, entre os homens, convencionou-se realizar por um movimento semelhante com o dedo indicador ou a cabeça. Assim, a reação da máquina demonstra que a ela pertence o posto de autoridade, o poder decisório de fornecer licença para qualquer movimento, ou, aproveitando a metáfora trazida pelo instrumento de medição de tempo usado no âmbito musical (metrónomo), pode-se dizer que a cena indica quem dará o tom dos acontecimentos por toda a narrativa.

O primeiro signo da transformação do carro em um animal surgiu já quando o homem saíra de casa e o encontrara na rua pela manhã: "O automóvel apareceu-lhe coberto de gotículas ${ }^{63}$, os vidros tapados de humidade. Se não fosse o frio tanto, poderia dizer-se que transpirava como um corpo vivo" 64 . A ambiguidade logo se faz notar, estendendo-se por uma sequência de outras referências análogas, desde o motor que, "com aquele rumor inaudível de pulmões enchendo e esvaziando, enchendo e esvaziando" 65 , "roncou alto, com um arfar profundo e impaciente" "66 "como se suspirasse" ${ }^{\prime 67}$, para arrancar "raspando o asfalto como um animal de cascos, triturando o lixo espalhado"68, parecendo "serpentear" 69 com um "frémito animal"70, uma "agilidade de animal" 71 — mais do que isso, aliás, um demoníaco e monstruoso animal de ares mitológicos: "O diabo do carro tinha sete fôlegos"72, segundo ele observa — até a súbita aproximação do carro ao posto de abastecimento, com o comportamento de "um perdigueiro que acode ao cheiro" ". A imagem do cão de caça contrasta com a que é legada ao homem: a do fragilizado cachorro lastimoso, que logo estará "a chorar baixinho, num ganido, miseravelmente" 74 e que, aliás, atrai a atenção de outro cão que "veio ladra-lhe, esquálido e sem convicção, à porta do carro" 75 .

$\mathrm{Na}$ animalização do carro que abandona o seu estado inanimado e na também reificação do homem que o reduz a um ser que é apenas parte de um objeto, os dois seres fazem encontrar seus níveis de existência, cada um na verdade em seu
62. Ibidem, p. 41.

63. Parece fértil perceber que essa característica do automóvel é muito semelhante à vidraça "escorrente de transpiração condensada" (33) — respiração do casal que dorme? suor da própria janela? — do parágrafo inicial do conto, objeto o qual, efetivamente, através de seu "olho esquadrado" (33), aparece como uma sugestão de certa natureza de Big Brother orwelliano: "O olho cinzento da vidraça foi-se azulando aos poucos, fitando fixo as duas cabeças pousadas na cama" (33), como algo que espreita em silêncio o inimigo aguardando a oportunidade de realizar o seu ataque, seu bote animal.

64. Ibidem, p. 34.

65. Ibidem, p. 39.

66. Ibidem, p. 35.

67. Ibidem, p. 38.

68. Ibidem, p. 35.

69. Ibidem, p. 35

70. Ibidem, p. 35.

71. Ibidem, p. 37.

72. Ibidem, p. 37

73. Ibidem, p. 36.

74. Ibidem, p. 42.

75. Ibidem, p. 42. 
76. Análise de outros contos dessa coletânea de José Saramago realizamos no artigo "Saramago quase", publicado na Revista Augustus, da Unisuam, em 2011. Aprofundando-nos ainda na leitura do conto "Coisas", já citamos o artigo "Coisas' de Saramago", que publicamos nas Atas do X Congresso da Associação Internacional de Lusitanistas intituladas Avanços em Literatura e Cultura Portuguesas - Século XX, em 2012.

77. COSTA, Horácio. José Saramago - o periodo formativo, 1997, p. 341-2.

78. SARAMAGO, José. Objecto quase, 2004, p. 38.

79. Ibidem, p. 38. devir-animal particular os quais partem de lados opostos, simultaneamente ao encontro e de encontro um do outro, gerando esse ser híbrido internamente conflituoso que configura a visão moderna de um personagem mítico, referido em outro conto de Objecto quase $e^{76}$ : o Centauro. E se a sociedade atual não permite a vivência deste, como a quinta narrativa do livro discutirá, o mesmo correrá em "Embargo" a essa nova criatura nascida do amálgama de outras duas, ciborgue a partir do homem e do seu automóvel, aquela que o substitui e ocupa o seu espaço — com algum nível também de frankesteinismo. Ora, Horácio Costa vislumbrara em "Centauro" um "universo em que o conflito básico se dá menos entre o animal e o humano e sim entre o objectual e o humano, numa época em que o homem, inconsciente dos seus atributos, antes de explorar a sua animalidade prefere - muito pior — reduzir-se a coisa"77. Nesse mesmo sentido, "a sucessão de gestos [em que] puxou o retrovisor e olhou-se no espelho"78 — e vislumbramos novamente o monstro-espelho do homem de que falara Santiesteban - cria a imagem necessária à constatação da metáfora, por se tratar de, no corpo do automóvel, verificar não o rosto de uma máquina, mas o do próprio homem (como seria o busto do ser humano na estrutura equina que configura o Centauro), com expressão ainda dotada (ao menos na primeira oportunidade) de predicados humanos: "Viu que estava perplexo e verificou que tinha razão"79 — sentença cujos sentidos oscilam ambiguamente na expressão tinha raz̃ão que significaria apenas estar certo ou, mais amplamente, ser dotado de faculdades mentais. Pois tais atributos, perplexidade e razão, ao se refletirem assim no automóvel, serão gradativamente a ele transferidos.

Contudo, José Saramago, evidentemente, não faz da obra de Kafka tabula rasa para o seu conto. A metamorfose é antes um palimpsesto sobre o qual o escritor português escreve uma narrativa em que o kafkiano comparecerá para além da temática. Se na novela centenária constatamos um Samsa que se torna outro em relação aos mesmos que lhe rodeiam não apenas e necessariamente em função da sua metamorfose mas pela queda de uma máscara social que ocultava essa sua identidade subjetiva, diríamos que em "Embargo" essa circunstância se radicaliza ainda mais. Ora, verificamos que o conto do monstro meio homem meio máquina denuncia a escravização e destruição do homem pelo objecto ou a situação de dependência imposta ao homem contemporâneo pelas técnicas de reprodução da sociedade de consumo; e, já que tal condição incide sobre todo cidadão comum da urbe moderna, esses homens fabricados em linhas de produção que se isolam uns dos outros em suas cápsulas de transitar pela cidade — casulo quente e embaciado que os isola do mundo — , a monstruosidade, uma vez regular (cotidiana como o elemento fantástico na poética kafkiana), igualmente não reside na sua metamorfose propriamente 
dita, mas na tomada de consciência dessa condição sua (novamente como Samsa) e dos membros da sociedade vigente e, no caso do herói saramaguiano, na sua reação (aí sim singular em relação aos demais) de subverter essa lógica imposta pelos lucros de indústrias como a automotiva e do capital especulativo com a commodity petróleo, ao intentar, algo ineditamente, esvencilhar-se do carro.

Para tanto, é preciso que se afaste da cidade (tornar-se tão radicalmente outro o segrega), a fim de que pudesse negar a sua lógica. Fará isso, então, solitariamente. Não é por acaso que o conto se desenvolve no Natal, data que conflui as crenças religiosas fundadoras da civilização ocidental e os motores da sociedade capitalista, sendo mesmo sua data comercial mais importante. Mas, ainda que se tratasse de "Um Natal escuro e frio" ${ }^{80}$, como ele lê na manchete do jornal, análise reiterada logo depois pelas notícias do rádio, esse contexto não impede que os cidadãos cumpram as funções consumidoras a que estariam programados desempenhar: "Tempo de Natal, mesmo faltando a gasolina, toda a gente vem para a rua" ${ }^{\prime 1}$. O resultado empreendido pelo protagonista, todavia, será falho e revela a impossibilidade de o homem contemporâneo perverter essa dialética da alienação e da reificação, uma vez que apenas no fenecimento a ruptura homem-máquina ocorre: a morte do personagem a qual encontra par na do próprio carro que, no jargão automobilístico popular, quando falha o seu motor, também "morre":

Às apalpadelas, abriu a porta para se libertar da sufocação que aí vinha, e nesse movimento, porque fosse morrer ou porque o motor morrera, o corpo pendeu para o lado esquerdo e escorregou do carro. Escorregou um pouco mais, e ficou deitado sobre as pedras. A chuva recomeçava a cair. ${ }^{82}$

O fato de a ruptura entre o personagem e o objeto ter a morte de ambos como saldo final (conforme aliás se repete em outros contos do livro: a morte do ditador ao se separar de sua cadeira ou a do Centauro na cisão entre sua parte homem e sua parte cavalo, por exemplo) comprova a impossibilidade física na economia do conto, mas sócio-político-econômica em referência ao contexto real que a narrativa questiona, de alforriar o homem moderno do seu automóvel (que no imaginário social torna-se símbolo cultural do estilo de vida das sociedades industriais de produção e consumo e individualistas do último século, a acompanhar notadamente os meninos — porque essa sociedade será também misógina — já desde a infância em seus brinquedos), já que, como sugere o fenecimento dessa criatura simbiótica em "Embargo", ela já se tornara um indivíduo, isto é, aquele que não pode ser dividido.
80. Ibidem, p. 36.

81. Ibidem, p. 38.

82. Ibidem, p. 46 
83. Ibidem, p. 43.

84. Ibidem, p. 34.
E essa morte sob a chuva o identifica com a grotesca imagem, que perpassou o conto a lhe antecipar o destino, do "rato morto na berma do passeio, [...] rato mole, de pêlo arrepiado" 83 em frente ao seu prédio, no qual cospe um menino logo no início "como lhe tinham ensinado e sempre via fazer" ${ }^{84}$ e cujo corpo, mais à frente, escorregará rua abaixo levado pela força da água da sarjeta. Sua sorte é a mesma desse ser asqueroso e sem vida, como fora a mesma do herói do conto de Herberto Helder que se isolara em si mesmo em um mundo que estava no fundo do seu espelho, a mesma do homem transmudado em cavalo branco que nas estratégias de um (quiçá alegórico) jogo de xadrez é sacrificado por causa de um xeque ao rei que nem sequer seria xeque-mate na narrativa de Álvaro Guerra, a mesma de Gregor Samsa cuja família decide por eliminá-lo na novela de Kafka: a da segregação a que, em um mundo que não suporta uma dinâmica de alteridade que lhe impeça o funcionamento das engrenagens segundo prescrito por interesses pretensamente gerais que ignoram subjetividades (a tão difícil individuação para os homens), estarão condenados esses monstros que afinal clamam pela identidade que lhes houvera sido alienada.

\section{Referências}

ADORNO, Theodor W. “Anotações sobre Kafka". In: . Prismas - crítica cultural e sociedade. Trad. Augustin

Wernet; Jorge Mattos Brito de Almeida. São Paulo: Ática, 1998, p. 239-70.

ALBUQUERQUE JÚNIOR, Durval Muniz de. "No castelo da história só há processos e metamorfoses, sem veredicto final". In: PASSET'TI, Edson (org.). Kafka, Foucault: sem medos. Cotia: Ateliê Editorial, 2004, p. 13-32.

BORGES, Jorge Luis. "Kafka e seus precursores". In: . Outras inquisiçoes. Trad. Davi Arrigucci Jr. São Paulo: Companhia das Letras, 2007, p.127-30.

CASTILHO, João. "Quando a fotografia (não) é texto? Metamorfose (imagem)". Em Tese. Belo Horizonte: FALE UFMG, v. 19, n. 13, Maio-Agosto 2013, p. 276-303. Disponível online: http://periodicos.letras.ufmg.br/index.php/emtese/ article/view/5279/4672. Acesso em 29/08/2016.

CARONE, Modesto. Lições de Kafka. São Paulo: Companhia das Letras, 2009. 
CASTRO, E. M. de Melo e (org.). Antologia do conto fantástico português. Lisboa: Edições Afrodite, 1974.

COHEN, Jefferey Jerome. "A cultura dos monstros: sete teses”. In: DONALD, James; HUNTER, Ian; COHEN, Jeffrey Jerome; GIL, José. Pedagogia dos monstros - os prazeres e os perigos da confusão de fronteiras. Trad. Tomaz Tadeu da Silva. Belo Horizonte: Autêntica, 2000, p. 23-60.

COSTA, Horácio. "Alegorias da desconstrução urbana: The memoirs of a survivor, de Doris Lessing, e Ensaio sobre a cegueira, de José Saramago". In: BERRINI, Beatriz. José Saramago - uma homenagem. São Paulo: Educ, 1999, p. 127-48.

1997. - José Saramago - o período formativo. Lisboa: Caminho,

CRUZ, Celso Donizete. “Introdução”. In: KAFKA, Franz. A metamorfose. Trad. Celso Donizete Cruz. São Paulo: Hedra, 2009 , p. 9-27.

CUADRADO, Perfecto E.. "Objecto quase e o estatuto das obras menores". In: MEDEIROS, Paulo de; ORNELAS, José N.

(org.). Das possibilidades do impossivel. Utrecht: Portuguese Studies Center, 2007, p. 41-9.

DELEUZE, Gilles; GUATTARI, Félix. Kafka - para uma literatura menor. Trad. Rafael Godinho. Lisboa: Assírio \& Alvim, 2003.

FERREIRA, António. Embargo. Portugal/Brasil/Espanha: Persona Non Grata Pictures, 2010 (filme).

FOUCAULT, Michel. História da loucura na Idade Clássica. Trad. José Teixeira Coelho Netto. São Paulo: Perspectiva, 1978. . Os anormais: curso no Collège de France (1974 - 1975).

Trad. Eduardo Brandão. São Paulo: Martins Fontes, 2001.

GIL, José. "Metafenomenologia da monstruosidade: o devirmonstro". In: DONALD, James; HUNTER, Ian; COHEN, Jeffrey Jerome; GIL, José. Pedagogia dos monstros - os prazeres e os perigos da confusão de fronteiras. Trad. Tomaz Tadeu da Silva. Belo Horizonte: Autêntica, 2000, p. 165-183.

GUERRA, Álvaro. Memória. Lisboa: Editorial Estampa, 1971.

HELDER, Herberto. Os passos em volta. Rio de Janeiro: Azougue Editorial, 2005.

JEHA, Julio. "Monstros como metáfora do mal". In: Monstros e monstruosidades na literatura. Belo Horizonte:

EdUFMG, 2007, p. 9-31. 
KAFKA, Franz. A metamorfose. Trad. Celso Donizete Cruz. São Paulo: Hedra, 2009, p. 9-27.

- A metamorfose. Trad. Modesto Carone. São Paulo:

Companhia das Letras, 1997.

. Die fferwandlung. Leipzig: Kurt Wolff Verlag, 1916.

. O castelo. Trad. Modesto Carone. São Paulo:

Companhia das Letras, 2008.

. O processo. Trad. Álvaro Gonçalves. Lisboa: Assírio \&

Alvim, 2001.

KUBRICK, Stanley. 2001: a space odyssey. Estados Unidos/

Reino Unido: Metro-Goldwyn-Mayer, 1968 (filme).

LACAN, Jacques. O seminário - livro 1: os escritos técnicos de Frend. Trad. Betty Milan. Rio de Janeiro: Zahar, 1979.

LOPES, João Marques. Saramago - biografia. São Paulo: Leya, 2010.

MAGALHÃES, Célia. Os monstros e a questão racial na narrativa modernista brasileira. Belo Horizonte: EdUFMG, 2003.

MARGARIDO, Alfredo. A centopeia. Lisboa: Guimarães, 1961. . No fundo deste canal. Lisboa: Arcádia, 1960.

MEAD, George Herbert. Mind, self and society. Chicago:

University of Chicago Press, 1934.

MICHELANGELO. "Creazione di Adamo". Coleção Gênio da Arte - Michelangelo. Trad. Mathias de Abreu Lima Filho. Barueri: Girassol, 2007, v. 3, p. 29 (pintura).

NAZÁRIO, Luiz. Da naturez̧a dos monstros. São Paulo: Arte \& Ciência, 1998.

NEVES, Margarida Braga. “'Nexos, temas e obsessões' na ficção breve de José Saramago". Revista Colóquio/Letras. Lisboa: Fundação Calouste Gulbenkian, no 151/152, janeiro de 1999, p. $117-41$.

ORWELL, George. 1984. Trad. Alexandre Hubner; Heloisa Jahn. São Paulo: Companhia das Letras, 2010.

PASSETTI, Edson. "Foucault-Kafka, sem medos". In: (org.). Kafka, Foucault: sem medos. Cotia: Ateliê Editorial, 2004, p. 9-12.

QUINET, Antonio. Os outros em Lacan. Rio de Janeiro: Zahar, 2012. 
REIS, Carlos. "Derivas: do conto ao romance em José Saramago". In: GREENFIELD, John (org.). O gênero literário norma e transgressão. Munchen: Martin Meidenbauer, 2006, p. 147-65.

SANTIESTEBAN, Héctor. "El monstruo y su ser". Revista Relaciones - Estudios de historia y sociedad. Zamora: El Colegio de Michoacán, v. 21, n. 81, Invierno de 2000, p. 93-126.

SARAMAgO, José. Ensaio sobre a cegueira. São Paulo: Companhia das Letras, 2007.

Objecto quase. São Paulo: Companhia das Letras, 2004.

SEIXO, Maria Alzira. "Recensão crítica a Objecto quase, de José Saramago". Revista Colóquio/Letras. Lisboa: Fundação Calouste Gulbenkian, no 49, maio de 1979, p. 77-9. Disponível online: http://coloquio.gulbenkian.pt/bib/sirius.exe/issueContentDis play? $\mathrm{n}=49 \& \mathrm{p}=77 \& \mathrm{o}=\mathrm{r}$. Acesso em 29/08/2016.

SOARES, Marcelo Pacheco. "Coisas de Saramago". Avanços em Literatura e Cultura Portuguesas - Século XX. Vol. 1. Santiago de Compostela; Faro: Associação Internacional de Lusitanistas; Através Editora, 2012, p. 147-63.

“Como apalpar o impalpável?! Leitura intertextual do conto kafkiano "A Pousada", de Agustina Bessa-Luís". Revista Veredas. Santiago de Compostela: Associação Internacional de Lusitanistas, no 22, Julho-Dezembro de 2014, p. 49-60. " "Saramago quase". Revista Augustus. Rio de Janeiro: Unisuam Publicações, no 31, Fevereiro de 2011, p. 22-31. Disponível online: http://apl.unisuam.edu.br/augustus/index. php?option $=$ com_content\&view $=$ article\&id $=267$ :saramagoquase $\&$ catid $=71$ :edicao-31-artigos $\&$ Itemid $=40$. Acesso em 29/08/2016.

SPIELBERG, Steven. E. T. - The extra-terrestrial. Estados Unidos: Universal Pictures, 1982 (filme). 
